\title{
Proposed nomenclature for samarskite-group minerals: new data on ishikawaite and calciosamarskite
}

\author{
S. L. HANSON ${ }^{1}$ \\ University of Utah, Department of Geology and Geophysics, 717 WBB, Salt Lake City, Utah, 84112-1183.
}

W. B. Simmons, A. U. Falster

University of New Orleans, Department of Geology and Geophysics, New Orleans, Louisiana 70148.

E. E. FOORD* AND F. E. Lichte

MS 905, U. S. Geological Survey, Box 25046, Denver Federal Center, Denver, Colorado 80225

\section{ABSTRACT}

The current definition of samarskite-group minerals suggests that ishikawaite is a uranium rich variety of samarskite whereas calciosamarskite is a calcium rich variety of samarskite. Because these minerals are chemically complex, usually completely metamict, and pervasively altered, their crystal chemistry and structure are poorly understood. Warner and Ewing (1993) proposed that samarskite is an $A^{3+} B^{5+} \mathrm{O}_{4}$ mineral with an atomic arrangement related to $\alpha-\mathrm{PbO}_{2}$. X-ray diffraction analyses of the recrystallized type specimen of ishikawaite and the Ca-rich samarskite reveal that they have the same structure as samarskite-(Y) recrystallized at high temperatures. Electron microprobe analyses show that the only significant difference between samarskite-(Y), ishikawaite, and calciosamarskite lies in the occupancy of the $A$-site. The $A$-site of samarskite-(Y) is dominated by $\mathrm{Y}+R E E$ whereas the $A$-site of ishikawaite is dominantly $\mathrm{U}+\mathrm{Th}$ and calciosamarskite is dominantly Ca. Additionally, a comparison of these data to those of Warner and Ewing (1993) show that in several cases $\mathrm{Fe}^{2+}$ or $\mathrm{Fe}^{3+}$ are dominant in the $A$-site. We propose that the name samarskite- $(R E E+Y)$ should be used when one of these elements is dominant and that the mineral be named with the most abundant of these elements as a suffix. The name ishikawaite should be used only when $U+T h$ are dominant and the name calciosamarskite should only be used when $\mathrm{Ca}$ is the dominant cation at the $A$-site. Finally, because of the inability to quantify the valence state of iron in these minerals, the exact nature of the valence state of iron in these minerals could not be determined in this study.

KEYWORDS: samarskite group, ishikawaite, calciosamarskite, metamict state.

\section{Introduction}

IshiKawaite $\left[(\mathrm{U}, \mathrm{Fe}, \mathrm{Y}, \mathrm{Ca})(\mathrm{Nb}, \mathrm{Ta}) \mathrm{O}_{4}\right]$ was first described as a uranium rich, REE-poor mineral by Kimura (1922). Ohashi (1924) suggested that a crystallographic relationship exists between ishikawaite and samarskite. Černý and Ercit (1989) describe ishikawaite as a probable uranium-rich

\footnotetext{
*Deceased 8 January 1998

${ }^{1}$ Present address: Earth Sciences Department, Adrian College, Adrian, MI 49221, U.S.A..
}

variety of samarskite. Currently, no published data are available to substantiate this relationship. Calciosamarskite was first described as a calciumrich variety of samarskite by Ellsworth (1928). However, Hogarth (1977) suggested that calciosamarskite may be a pyrochlore group mineral. Nickel and Nichols (1991) indicate it to be a discredited mineral species. However, because no formal proposal was submitted to discredit this mineral it is still considered a valid mineral species by the CNMMN (E. H. Nickel, personal communication). Because these complex Nb-TaTi oxides are generally completely metamict and pervasively altered, their crystal chemistry and

(C) 1999 The Mineralogical Society 


\section{S. L. HANSON ETAL.}

structure are poorly understood. Samples of the type specimen of ishikawaite from Ishikawa Prefecture, Iwaki, Japan and a uranium-rich samarskite from Kunar, Afghanistan, have been examined by X-ray diffraction, electron microprobe and LA-ICP-MS analysis in order to infer the crystal structure and chemistry of ishikawaite as well as to determine the nature of its relationship to samarskite. A Ca-rich sample from Mitchell Co., North Carolina, was also studied to determine if calciosamarskite should be considered a valid mineral species. Additionally, the samarskite data of Warner and Ewing (1993) are included in the evaluation on the basis of mineral chemistry in an effort to establish a proper nomenclature for these minerals.

\section{Analytical methods}

Samples were analysed at the University of Utah on a CAMECA SX-50 microprobe with an accelerating voltage of $15 \mathrm{kV}$, a beam current of 30 nanoamps and counting times of between 20 and 40 seconds. A $3 \mu \mathrm{m}$ beam size was used to ensure analysis of inclusion-free phases. Peak overlaps within the REE were avoided by using the $L \alpha$ peak positions for $\mathrm{La}, \mathrm{Ce}, \mathrm{Eu}, \mathrm{Gd}, \mathrm{Tb}, \mathrm{Ho}$, $\mathrm{Tm}$ and $\mathrm{Yb}$, and $L \beta$ peak positions for $\mathrm{Pr}, \mathrm{Nd}, \mathrm{Sm}$, Dy and Er. Standards were: Y-niobate $(\mathrm{Nb})$, manganotantalite $(\mathrm{Ta})$, rutile $(\mathrm{Ti}), \mathrm{W}$ metal $(\mathrm{W})$, diopside $(\mathrm{Ca}, \mathrm{Si})$, hematite $(\mathrm{Fe})$, rhodonite $(\mathrm{Mn})$, YAG (Y), cubic zirconia ( $\mathrm{Zr})$, Sc metal ( $\mathrm{Sc}$ ), crocoite $(\mathrm{Pb})$, cassiterite $(\mathrm{Sn})$, synthetic $\mathrm{UO}_{3}(\mathrm{U})$, and a synthetic $\mathrm{NaTh}_{2}\left(\mathrm{PO}_{4}\right)_{3}(\mathrm{Th})$. REE standards include: Drake and Weill glasses (Drake and Weill, 1972), synthetic REE garnets (U. S. National Museum numbers: S-65, S-67, S-68, S87, S-90, S-92, and S-529) and synthetic REE phosphates (from the Smithsonian Institution). Matrix effects were corrected using a $\phi(\rho Z)$ correction procedure (Pouchou and Pichoir, 1991).

The Kunar sample was also analysed by laser ablation inductively coupled plasma mass spectrometry (LA-ICP-MS). A VG Plasmaquad II+ equipped with a Spectron Inc. Nd/YAG laser operated at the primary wavelength $(1064 \mathrm{~nm})$ was used for this study. A single mineral grain was glued onto a white poly-propylene surface and placed into an enclosed sample cell. The power and frequency of laser firings were adjusted to ablate material from the surface of the mineral grain at a controlled rate. A typical protocol used 350 mJoules per laser shot at $5 \mathrm{~Hz}$ in the fixed switched mode. The power was increased in 50 mJoule increments to ablate more material until an adequate mass spectrometric signal was obtained. If the coupling efficiency between sample and laser energy was low, the process was repeated under Q-switched conditions. The instrument was calibrated from a glass standard containing all of the elements of interest using laser conditions that were similar to those used for the mineral grain.

Total water was determined by heating about $40 \mathrm{mg}$ of sample with $300 \mathrm{mg}$ of lead chromate, lead oxide, and calcium carbonate flux at $900-950^{\circ} \mathrm{C}$. The evolved water was quantified by using a Mitsubishi CA-05 coulometric Karl Fischer titrator (Jackson, 1987).

X-ray diffraction analyses were carried out at the University of New Orleans using a Scintag $\mathrm{XDS}-2000 \mathrm{X}$-ray diffractometer, $\mathrm{Cu}-\mathrm{K} \alpha$ radiation and a scan rate of $0.5^{\circ} 2 \theta$ per minute. Standards for instrument calibration include corundum and quartz. Cell parameters were calculated using 24 to 27 reflections between $8^{\circ}$ and $63^{\circ} 2 \theta$ with CELL, a modified IBM-PC version of the least squares refinement program of Appleman and Evans (1973).

\section{Appearance and physical properties}

Ishikawaite from Kunar (Afghanistan) and Ishikawa occur as black, glassy anhedral masses with a brown to black streak. They are opaque with vitreous luster. Cleavage and parting are absent as the minerals are partially to completely metamict. Fracture is conchoidal. The hardness of ishikawaite is $5-6$ and the specific gravity is $6.2-6.4 \mathrm{~g} / \mathrm{cm}^{3}$ (Palache et al., 1944).

The calciosamarskite from North Carolina occurs as black, glassy anhedral masses with a brown to black streak. It is opaque with a vitreous luster and has a hardness of 5 to 6 . No cleavage or parting are present as the mineral is completely metamict. Fracture is conchoidal. Density was measured on a Berman Density Balance which yielded a value of $5.8(0.1) \mathrm{g} / \mathrm{cm}^{3}$. The optical properties of this mineral are difficult to constrain due to the opaque nature of the mineral. The refractive indices are $>2.0$ as determined by measuring in molten sulphur-selenium.

\section{X-ray diffractometry}

In order to evaluate the relationship of ishikawaite and calciosamarskite to samarskite, the crystal 


\section{THE SAMARSKITE GROUP}

chemistry of samarskite must first be considered. Because of the metamict nature of these minerals, crystal structure analysis eluded workers for a long time. Komkov (1965), based on analyses of samarskite heated to $660^{\circ} \mathrm{C}$, showed that the crystal structure is derived from that of $\alpha-\mathrm{PbO}_{2}$ with cell dimensions similar to that of wolframite. Thus, samarskite has two octahedrally coordinated cation sites with the general formula $A \mathrm{BO}_{4}$ Sugitani et al. (1984, 1985) suggested that there are low and high temperature forms of samarskite with the conversion occuring at $950^{\circ} \mathrm{C}$. They suggested that the low-temperature form is orthorhombic, whereas the high-temperature form, apparently due to an ordering phenomenon, has a doubled $b$ cell dimension and a distortion to a monoclinic structure. These authors also showed that samarskite is a derivative of the $\alpha-\mathrm{PbO}_{2}$ structure but suggested that it may be related to either an ixiolite-type or columbite-type structure (low-temperature form) or a wolframite-type structure (high-temperature form). Sugitani et al. (1985), based on electron microprobe analyses of a synthetic samarskite, proposed a general formula of $A_{3} B_{5} \mathrm{O}_{16}$ for samarskite. This led to a reclassification of samarskite by the International Mineralogical Association Commission on New Minerals and Mineral Names (CNMMN). However, due to difficulties in correlating this formula with X-ray diffraction parameters (Komkov, 1965; Sugitani et al., 1984; 1985), Sugitani et al. (1985) proposed that samarskite may be only partially ordered to completely disordered with the general formula $\mathrm{MO}_{2}$. Recently, Warner and Ewing (1993) used electron microprobe analyses of natural samarskite to show that samarskite chemistry conforms to a wolframite-type $\left(A \mathrm{BO}_{4}\right)$ structure as originally suggested by Komkov (1965). This led to yet another reclassification for samarskite by CNMMN. Furthermore, they propose that the high-temperature polymorph of samarskite may be a derivative of the $A \mathrm{BO}_{4}$ structure in that the $A$-site cations may be partitioned into $A$ - and $\mathrm{A}^{\prime}$-sites based on ionic radii.

Finally, although Sugitani et al. (1985) produced the high-temperature polymorph in the laboratory, it is unlikely that it occurs naturally. The low temperature at which pegmatites crystallize precludes the growth of the high-temperature polymorph.

The sample from Ishikawa is only partially metamict as it exhibits a few diffraction peaks whereas samples from Kunar (Afghanistan) and
Mitchell Co., N.C., are completely metamict as they show no diffraction peaks. Preceding X-ray analysis, samples were recrystallized by heating to a temperature of $1100^{\circ} \mathrm{C}$ for 12 hours in a reducing atmosphere mixture of $95 \% \mathrm{Ar}$ and 5\% H (Sugitani, 1984; 1985). Tables 1 and 2 show indexed X-ray diffraction patterns, $d$-spacings and cell parameters for Ishikawa, Kunar, and Mitchell Co. samples compared to the high-temperature samarskite of Sugitani et al. (1985). Both the $d$-spacings and the cell edges of these samples are nearly identical to those of the samarskite of Sugitani (1985), suggesting they both take the same structure as samarskite upon heating. It is important to note that the X-ray diffraction peaks are compared to the high-temperature polymorph simply for the purposes of identification. We in no way wish to imply that the high-temperature polymorph of samarskite represents the original structure of the sample.

\section{Mineral chemistry}

Although the X-ray diffraction data of Komkov (1965) and Sugitani et al. $(1984,1985)$ show that the structure of samarskite is a derivative of the $\alpha$ $\mathrm{PbO}_{2}$ structure, these authors were never able to satisfactorily correlate this structure with samarskite crystal chemistry. In a comprehensive study of samarskite chemistry, Warner and Ewing (1993) provide compelling evidence for defining samarskite as an $A^{3+} B^{5+} \mathrm{O}_{4}$ mineral structurally derived from $\alpha-\mathrm{PbO}_{2}$. Thus, the current species definition for samarskite is $\left(\mathrm{Fe}^{3+}, \mathrm{Y}, \mathrm{Fe}^{2+}, \mathrm{U}, R E E\right)$ $(\mathrm{Nb}, \mathrm{Ta}) \mathrm{O}_{4}$ (Fleischer and Mandarino, 1995). However, we feel this formula is in error, as samarskite has historically been defined as a mineral with $\mathrm{Y}$, not $\mathrm{Fe}^{3+}$, dominant in the $A$-site (Komkov, 1965; Sugitani et al, 1985; Černý and Ercit, 1989). Furthermore, nearly all of the samples from the data set of Warner and Ewing (1995) have $\mathrm{Y}+R E E$ dominant at the $A$-site. Thus, further references in this paper to samarskite will be to the $\mathrm{Y}+R E E$ dominant phase, samarskite-(Y).

An average of 8 microprobe analyses of the Ishikawa sample, an average of 6 analyses for the Mitchell Co. sample, and an average of three microprobe analyses and one LA-ICP-MS analysis for the Kunar sample are given in Table 3 (oxide analyses) and Table 4 (empirical formulae). The original ishikawaite analysis from Kimura (1922) and the original calciosamarskite analysis (Ellsworth, 1928) are also included in Table 3. A comparison of the original ishikawaite 
S. L. HANSON ETAL.

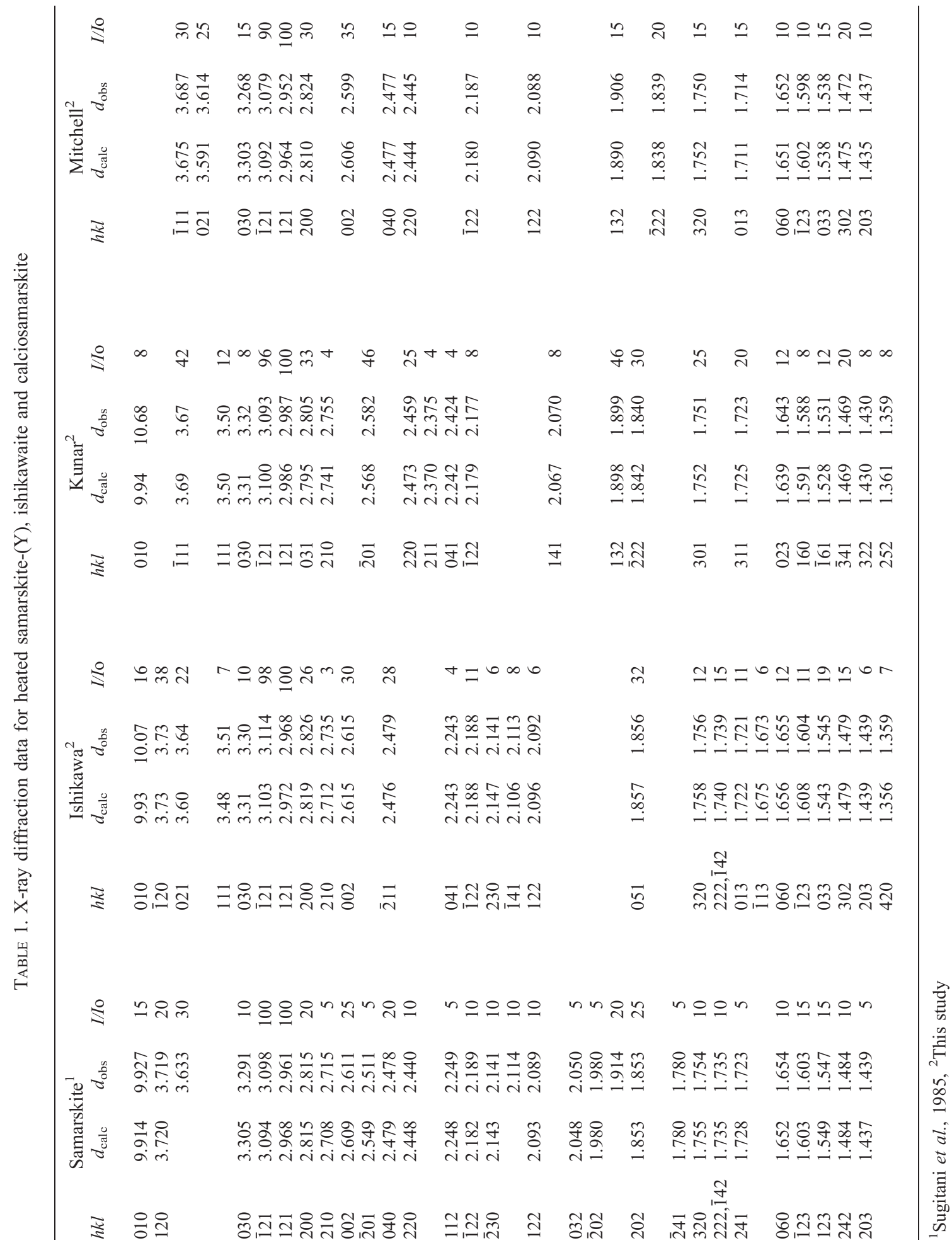




\section{THE SAMARSKITE GROUP}

TABLE 2. Cell parameters for samarskite-(Y), ishikawaite and calciosamarskite (in Angstroms)

\begin{tabular}{lllll}
\hline & \multicolumn{1}{c}{$a$} & \multicolumn{1}{c}{$b$} & \multicolumn{1}{c}{$c$} & \multicolumn{1}{c}{$\beta$} \\
\hline Kawabe* & 5.64 & 9.91 & 5.23 & 93.84 \\
Ishikawa & $5.652(0.011)$ & $9.934(0.013)$ & $5.243(0.044)$ & $93.95(0.13)$ \\
Afghan & $5.714(0.011)$ & $9.931(0.013)$ & $5.217(0.019)$ & $93.47(0.20)$ \\
Mitchell Co. & $5.632(0.016)$ & $9.912(0.022)$ & $5.221(0.008)$ & $93.87(0.14)$ \\
\hline
\end{tabular}

*From Sugitani et al., 1985

analysis to the electron microprobe data reveals a significant discrepancy in total $\mathrm{Fe}$ and Ta. This discrepancy occurs because the ishikawaite type specimen is a microscopic intergrowth of ishikawaite and ferrocolumbite. Thus, the bulk analysis of Kimura (1922) represents a mixture of the two minerals.

Oxide analyses were recalculated on the basis of 4 oxygens. The recalculations were done on an anhydrous basis because water present is attributed to adsorbed molecular water, a common feature of metamict minerals (Ewing, 1975). Iron is inferred to be present as both $\mathrm{FeO}$ and $\mathrm{Fe}_{2} \mathrm{O}_{3}$ and was calculated assuming of 2 atoms per formula unit. This method was chosen because the ideal metal to oxygen ratio is $1: 2$. Cation occupancies were initially assigned using the samarskite formula of Warner and Ewing (1993). Both $\mathrm{Nb}$ and $\mathrm{Ta}$ are assigned to the $B$-site. Because both cation sites are octahedrally coordinated, Ti may occur in either, or both sites. In the formulae, all $\mathrm{Ti}$ is placed in the $B$-site because the site totals are low. For the Kunar sample, this yields $A$-site atom sums of 0.985 and 1.001 and $B$-site atom sums of 1.015 and 0.999 for the microprobe and LA-ICP-MS analyses respectively. Corresponding to these site totals are charge sums of 3.079 and 3.10 for the $A$-site and 4.93 and 4.90 for the $B$-site. However, even with the addition of Ti to the $B$-site sum, total site occupancies for the Ishikawa sample are still high (1.051) for the $A$-site and low (0.949) for the $B$-site respectively. Additionally, the charge sums are low (4.73) for the $A$-site and high (3.27) for the $B$-site. For this reason we suggest that $\mathrm{Fe}^{3+}$ may also occur at the $B$-site. The addition of $\mathrm{Fe}^{3+}$ to the $B$-site has the following effect on the mineral formula. The cation sums for the $A$ - and $B$-sites still deviate slightly from ideality $(0.952$ and 1.048 respectively) but the charges are more consistent with the formula (5.03 and 2.97 respectively). However, it is possible that $\mathrm{Fe}^{3+}$ may be residing in either the $A$-site, or both the $A$ and $B$-sites, as ideal site charges do not need to be preserved if coupled substitution and a local charge balancing mechanism is occurring.

For the Mitchell Co. sample, the total cations are slightly high (2.145). This may simply be the result of slight errors in the analyses which cumulatively produce a larger error. As with the Kunar sample, $\mathrm{Nb}$, Ta and $\mathrm{Ti}$ are assigned to the $B$-site, yet the total number of atoms is slightly low for the $B$-site (0.903) and a slightly high total for the $A$-site (1.242). Corresponding to the deviation from unity of the site totals, the sum of the $B$-site charge is low (4.48) and similarly, the sum of the $A$-site charge is high (3.52). Placing all of the $\mathrm{Fe}^{3+}$ into the $B$-site results a high total (1.165) for the $B$-site and a slightly low total for the $A$-site (0.980) and yields high charges for the $B$-site and correspondingly low charges for the $A$-site. Thus, again it is likely that $\mathrm{Fe}^{3+}$ may reside in both sites. Although we have chosen to assign $\mathrm{Fe}^{3+}$ to the $B$-site for the Ishikawa sample and in the $A$-site for the Mitchell Co. sample, it is impossible to evaluate which cation site (if not both) $\mathrm{Fe}^{3+}$ resides in. Additionally, these calculated $\mathrm{Fe}^{2+}$ and $\mathrm{Fe}^{3+}$ values represent postmetamictization values and thus, may not represent the original pre-metamictization values.

The average $A$-site radius calculated is 0.084 $\mathrm{nm}$ for ishikawaite and $0.087 \mathrm{~nm}$ for calciosamarskite. Although this value is slightly high for calciosamarskite, these values are consistent with an $\alpha-\mathrm{PbO}_{2}$ structure type where both sites are octahedrally coordinated (Warner and Ewing, 1993).

$B$-site occupancy for samarskite-group minerals is such that $\mathrm{Nb}>\mathrm{Ta}$ and $\mathrm{Ti}$. One sample from the samarskite data set of Warner and Ewing (1993) contains $\mathrm{Ta}>\mathrm{Nb}$ in the $B$-site. However, current species definition for samarskite calls for $\mathrm{Nb}>\mathrm{Ta}$ thus, this specimen should be considered a new mineral which is isostructural with samarskite- 


\section{S. L. HANSON ETAL.}

TABLE 3. Chemical composition

\begin{tabular}{|c|c|c|c|c|c|c|}
\hline & Ishikawa $^{1}$ & Ishikawa $^{2}$ & Kunar $^{2}$ & Kunar $^{3,4}$ & Woodcox $^{5}$ & Mitchell $^{2}$ \\
\hline $\mathrm{Nb}_{2} \mathrm{O}_{5}$ & 36.80 & 37.8 & 38.6 & 39.6 & 43.32 & 37.4 \\
\hline $\mathrm{Ta}_{2} \mathrm{O}_{5}$ & 15.00 & 5.77 & 6.43 & 6.43 & 2.54 & 5.57 \\
\hline $\mathrm{TiO}_{2}$ & 0.21 & 0.45 & 4.4 & 3.07 & 2.50 & 1.17 \\
\hline $\mathrm{ThO}_{2}$ & & 3.27 & 3.71 & 2.85 & 3.34 & 3.75 \\
\hline $\mathrm{UO}_{2}$ & 21.88 & 31.8 & 18.6 & 19.0 & 9.00 & 17.9 \\
\hline $\mathrm{UO}_{3}$ & & & & & 1.67 & \\
\hline $\mathrm{La}_{2} \mathrm{O}_{3}$ & & b.d.l. & b.d.l. & 0.01 & & b.d.l. \\
\hline $\mathrm{Ce}_{2} \mathrm{O}_{3}$ & & 0.1 & 0.1 & 0.16 & & 0.05 \\
\hline $\mathrm{Pr}_{2} \mathrm{O} 3$ & & 0.06 & 0.1 & 0.04 & & 0.03 \\
\hline $\mathrm{Nd}_{2} \mathrm{O}_{3}$ & & 0.56 & 0.44 & 0.38 & & 0.50 \\
\hline $\mathrm{Sm}_{2} \mathrm{O}_{3}$ & & 0.29 & 0.23 & 0.39 & & 0.29 \\
\hline $\mathrm{Eu}_{2} \mathrm{O}_{3}$ & & b.d.1. & b.d.1. & b.d.1. & & b.d.l. \\
\hline $\mathrm{Gd}_{2} \mathrm{O}_{3}$ & & 1.17 & 1.02 & 0.59 & & 0.97 \\
\hline $\mathrm{Tb}_{2} \mathrm{O}_{3}$ & & 0.14 & 0.18 & 0.20 & & 0.11 \\
\hline $\mathrm{Dy}_{2} \mathrm{O}_{3}$ & & 0.85 & 1.66 & 1.80 & & 1.38 \\
\hline $\mathrm{Ho}_{2} \mathrm{O} 3$ & & 0.26 & 0.37 & 0.34 & & 0.21 \\
\hline $\mathrm{Er}_{2} \mathrm{O}_{3}$ & & 0.77 & 0.8 & 1.01 & & 0.38 \\
\hline $\mathrm{Tm}_{2} \mathrm{O}_{3}$ & & 0.09 & b.d.l. & 0.11 & & b.d.l. \\
\hline $\mathrm{Yb}_{2} \mathrm{O}_{3}$ & & 0.17 & 0.67 & 0.58 & & 0.48 \\
\hline $\mathrm{Lu}_{2} \mathrm{O}_{3}$ & & 0.11 & 0.17 & 0.08 & & 0.12 \\
\hline $\mathrm{Y}_{2} \mathrm{O}_{3}$ & & 3.04 & 7.64 & 7.30 & & 6.90 \\
\hline$R E E+\mathrm{Y}$ & 8.40 & & & & 13.06 & \\
\hline $\mathrm{MnO}$ & 0.40 & 2.02 & 1.39 & 1.38 & 0.04 & 0.79 \\
\hline $\mathrm{ZrO}_{2}$ & & 0.36 & b.d.l. & 0.16 & 0.02 & b.d.l. \\
\hline $\mathrm{CaO}$ & 0.86 & 0.07 & 0.32 & 0.72 & 7.56 & 6.17 \\
\hline $\mathrm{Sc}_{2} \mathrm{O}_{3}$ & & 0.05 & 0.48 & 0.11 & & 1.09 \\
\hline $\mathrm{SnO}_{2}$ & 1.20 & 0.12 & 2.98 & 3.28 & 1.49 & 0.10 \\
\hline $\mathrm{PbO}$ & & b.d.1. & b.d.l. & 0.18 & 0.44 & 0.70 \\
\hline $\mathrm{WO}_{3}$ & & 1.86 & 2.03 & 1.32 & & 1.83 \\
\hline $\mathrm{Fe}_{2} \mathrm{O}_{3}$ & & 2.64 & 4.95 & 5.97 & 7.67 & 7.40 \\
\hline $\mathrm{FeO}$ & 11.78 & 6.26 & 3.98 & 3.10 & 0.21 & \\
\hline $\mathrm{Al}_{2} \mathrm{O}_{3}$ & 0.87 & 0.22 & b.d.l. & 0.08 & 0.16 & 0.15 \\
\hline $\mathrm{SiO}_{2}$ & 0.30 & b.d.l. & b.d.l. & b.d.l. & 2.39 & 0.21 \\
\hline $\mathrm{MgO}$ & 1.07 & b.d.l. & 0.09 & 0.09 & 0.02 & 0.01 \\
\hline $\mathrm{Na}_{2} \mathrm{O}$ & & 0.03 & 0.03 & 0.09 & & 0.84 \\
\hline $\mathrm{BeO}$ & & n.a. & n.a. & n.a. & 0.26 & n.a. \\
\hline $\mathrm{H}_{2} \mathrm{O}$ & 0.89 & n.a. & n.a. & 0.80 & 3.64 & n.a. \\
\hline Total & 99.66 & 100.3 & 101.4 & 101.2 & 99.33 & 96.50 \\
\hline
\end{tabular}

b.d.1. = below detection limit

n.a. $=$ not analysed

${ }^{1}$ Kimura, 1922

${ }^{2}$ EPMA performed at Univ. of Utah

${ }^{3}$ LA-ICP-MS and EPMA performed at USGS

${ }^{4}$ All oxides are LA-ICP-MS analyses with the following exceptions: $\mathrm{Nb}_{2} \mathrm{O}_{5}, \mathrm{FeO} *$ are average of $2 \mathrm{EPMA}$; Ta $2 \mathrm{O}_{5}$, $\mathrm{UO}_{2}, \mathrm{Y}_{2} \mathrm{O}_{3}$ are average of 2 EPMA and LA-ICP-MS.

${ }^{5}$ Ellsworth, 1928

group minerals. Given this, a different unique name should be used to describe this mineral. For this reason, this sample is not included in the following discussion.
The only significant difference between ishikawaite, calciosamarskite and samarskite-(Y) involves $A$-site chemistry. Ishikawaite contains higher concentrations of $U$ and generally lower 
TABLE 4. Chemical formulae recalculated on the basis of 4 oxygens

\begin{tabular}{|c|c|c|c|c|}
\hline & Ishikawa & Kunar & Kunar & Mitchell \\
\hline $\mathrm{Nb}$ & 0.854 & 0.787 & 0.816 & 0.791 \\
\hline $\mathrm{Ta}$ & 0.078 & 0.079 & 0.080 & 0.071 \\
\hline $\mathrm{Ti}$ & 0.017 & 0.149 & 0.105 & 0.041 \\
\hline $\mathrm{Fe}^{3+}$ & 0.099 & & & \\
\hline Sum B & 1.048 & 1.015 & 1.001 & 0.903 \\
\hline Th & 0.037 & 0.038 & 0.030 & 0.040 \\
\hline $\mathrm{U}$ & 0.354 & 0.186 & 0.193 & 0.186 \\
\hline \multicolumn{5}{|l|}{$\mathrm{La}$} \\
\hline $\mathrm{Ce}$ & 0.002 & 0.002 & 0.003 & 0.001 \\
\hline $\operatorname{Pr}$ & 0.001 & 0.002 & 0.001 & \\
\hline $\mathrm{Nd}$ & 0.010 & 0.007 & 0.006 & 0.008 \\
\hline $\mathrm{Sm}$ & 0.005 & 0.004 & 0.006 & 0.005 \\
\hline \multicolumn{5}{|l|}{$\mathrm{Eu}$} \\
\hline $\mathrm{Gd}$ & 0.019 & 0.015 & 0.009 & 0.015 \\
\hline $\mathrm{Tb}$ & 0.002 & 0.003 & 0.003 & 0.002 \\
\hline Dy & 0.014 & 0.024 & 0.026 & 0.021 \\
\hline Ho & 0.004 & 0.005 & 0.005 & 0.003 \\
\hline $\mathrm{Er}$ & 0.012 & 0.011 & 0.014 & 0.006 \\
\hline $\mathrm{Tm}$ & 0.001 & & 0.002 & \\
\hline $\mathrm{Yb}$ & 0.003 & 0.009 & 0.008 & 0.007 \\
\hline $\mathrm{Lu}$ & 0.002 & 0.002 & 0.001 & 0.002 \\
\hline $\mathrm{Y}$ & 0.081 & 0.184 & 0.177 & 0.172 \\
\hline $\mathrm{Mn}$ & 0.086 & 0.053 & 0.053 & 0.031 \\
\hline $\mathrm{Zr}$ & 0.009 & & 0.004 & \\
\hline $\mathrm{Ca}$ & 0.004 & 0.016 & 0.035 & 0.309 \\
\hline $\mathrm{Sc}$ & 0.002 & 0.019 & 0.004 & 0.044 \\
\hline $\mathrm{Sn}$ & 0.002 & 0.054 & 0.060 & 0.002 \\
\hline $\mathrm{Pb}$ & & & 0.002 & 0.009 \\
\hline W & 0.024 & 0.024 & 0.016 & 0.022 \\
\hline $\mathrm{Fe}^{3+}$ & & 0.168 & 0.205 & 0.261 \\
\hline $\mathrm{Fe}^{2+}$ & 0.262 & 0.150 & 0.118 & \\
\hline $\mathrm{Al}$ & 0.013 & & 0.004 & 0.008 \\
\hline $\mathrm{Si}$ & & & & 0.010 \\
\hline $\mathrm{Mg}$ & & 0.006 & 0.006 & 0.001 \\
\hline $\mathrm{Na}$ & 0.003 & 0.003 & 0.008 & 0.077 \\
\hline Sum A & 0.952 & 0.985 & 0.999 & 1.242 \\
\hline
\end{tabular}

$R E E+Y$. Because $\mathrm{Th}^{4+}$ has a similar size and identical charge as $\mathrm{U}^{4+}$, it is likely substituting for $\mathrm{U}$, thus we choose to compare $\mathrm{U}+\mathrm{Th}$ to $R E E+\mathrm{Y}$. Calciosamarskite has more abundant $\mathrm{Ca}$ and generally lesser $R E E+Y$. Figure 1 is a plot of major $A$-site cations with the samarskite fields of Černý and Ercit (1989) superimposed on it. Samarskite analyses from Warner and Ewing (1993) are included for comparison. The Ishikawa sample is clearly enriched in $\mathrm{U}+\mathrm{Th}$ and plots just below the ishikawaite field of Černý and Ercit (1989). Analyses of the Kunar sample lie in

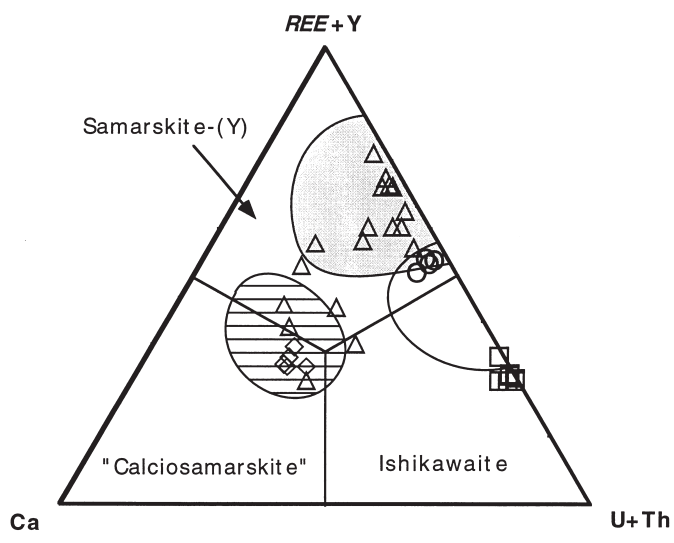

FIG. 1. Ternary diagram showing $A$-site occupancy of samarskite-group minerals. Symbols are as follows: Ishikawa (open squares); Kunar (open circles); Mitchell Co. (open diamonds) and; data from Warner and Ewing (1993) (open triangles). Fields from Černý and Ercit (1989) shown are samarskite (stippled), ishikawaite (unshaded), and calciosamarskite (horizontal lines).

the region of overlap between the ishikawaite and samarskite fields. The Mitchell Co. sample lies in their calciosamarskite field. Analysed samarskites from Warner and Ewing (1993) lie in the samarskite and calciosamarskite fields, as well as between the two. Given this classical ternary approach, it seems logical that the samarskite and ishikawaite fields should be divided on the basis of the dominant cation, as shown by the solid lines in Fig. 1, rather than by the fields of Černý and Ercit (1989) (Nickel, 1992). This leads to a definition of samarskite based on $A$-site occupancy with $\mathrm{Y}+R E E$ dominant at the $A$-site whereas ishikawaite has $\mathrm{U}+\mathrm{Th}$ dominant and calciosamarskite has $\mathrm{Ca}$ dominant at the $A$-site. Based on these subdivisions, analyses of the Ishikawa sample plot in the ishikawaite field whereas analyses of the Kunar sample fall in the samarskite field. Likewise, analyses of the Mitchell Co. sample plot in the calciosamarskite field. Only two analyses of Ewing's do not plot in our proposed samarskite field. One analysis lies in the ishikawaite field whereas the other plots as calciosamarskite.

However, defining samarskite-group minerals is more complex than this simple ternary relation suggests because iron $\left(\mathrm{Fe}^{2+}\right.$ and/or $\left.\mathrm{Fe}^{3+}\right)$ is often an abundant $A$-site cation. Figures $2 a-f$ are a series of plots which show the three most abundant $A$-site cations for each of the samples. Only one sample (Fig. $2 a$ ) has $R E E+\mathrm{Y}, \mathrm{U}+\mathrm{Th}$ and 

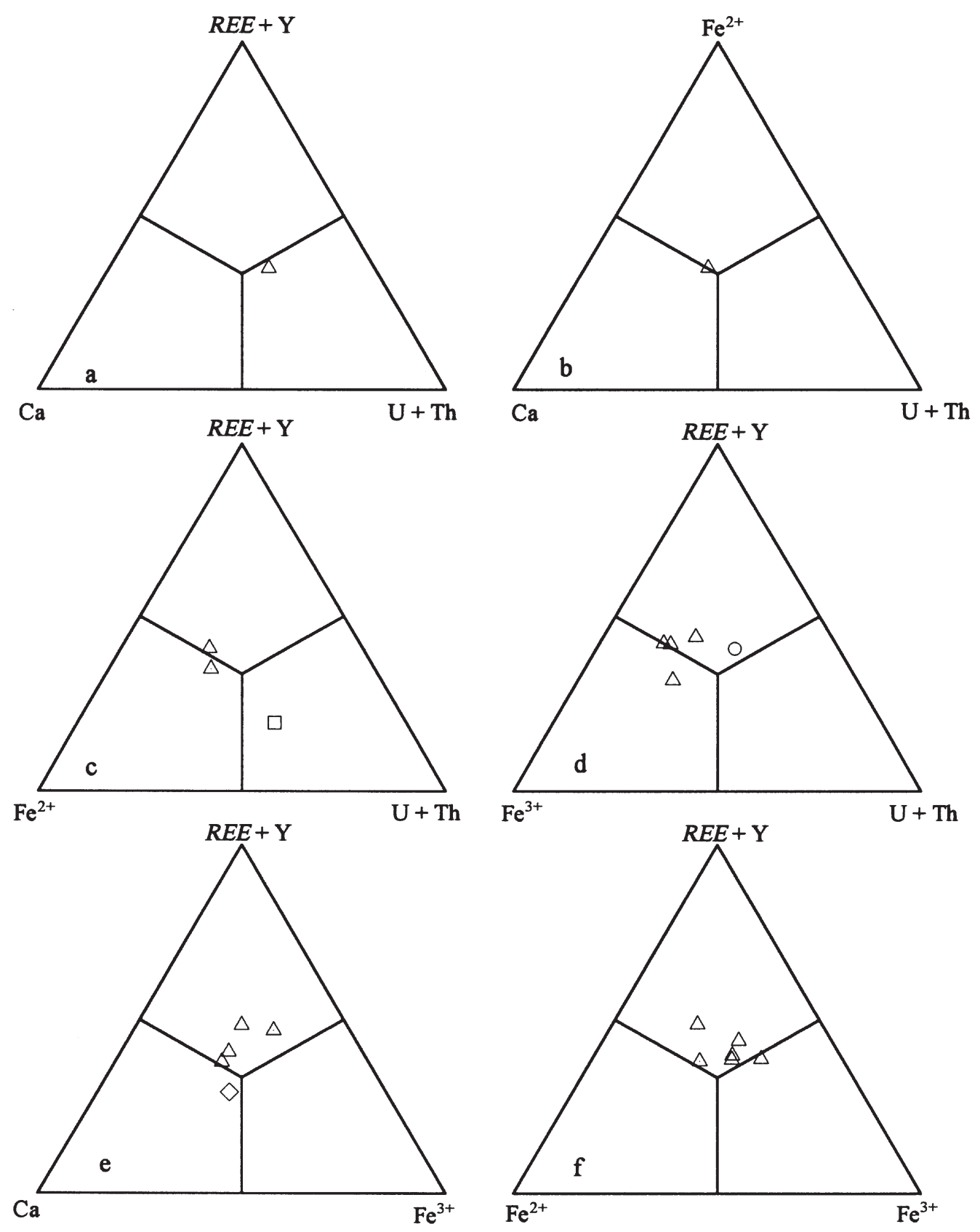

Fig. 2. Ternary diagrams $(a-f)$ showing the most abundant $A$-site cations for samarskite-group minerals. Symbols are as in Fig. 1.

$\mathrm{Ca}$ as the dominant $A$-site cations. For the remainder, either $\mathrm{Fe}^{2+}, \mathrm{Fe}^{3+}$, or both are represented in the dominant three $A$-site cations
(Figs. $2 b-f$ ). In spite of this, analyses of Ishikawa, Kunar, and Mitchell Co. samples still plot as ishikawaite, samarskite-(Y) and calciosa- 


\section{THE SAMARSKITE GROUP}

marskite respectively. Additionally, all analyses but four of the Warner and Ewing (1993) samples lie in the same field as in Fig. 1. The Ca-rich sample from Fig. 1 has equal amounts of $\mathrm{Ca}$ and $\mathrm{Fe}^{2+}$ thus, the analysis plots on the line dividing the fields. Two samples from Warner and Ewing (1993) have $\mathrm{Fe}^{3+}$ dominant and one has $\mathrm{Fe}^{2+}$ dominant. However, these results should be treated with suspicion as $\mathrm{Fe}^{2+}$ and $\mathrm{Fe}^{3+}$ are not measured but are calculated on site totals as described above. Thus, any analytical error in the other elements will introduce errors in the calculated ferrous and ferric values. Additionally, these calculated $\mathrm{Fe}^{2+}$ and $\mathrm{Fe}^{3+}$ values represent post-metamictization values and thus, may not reflect the original, pre-metamictization values.

Given the above data, we propose that samarskite-group minerals include three possible species based on $A$-site occupancies. If $R E E+\mathrm{Y}$ is dominant, the mineral should be named samarskite- $(R E E+\mathrm{Y})$ with the dominant of these cations as a suffix (Nickel and Mandarino, 1987). If $U+$ Th are dominant, the mineral should be named ishikawaite. Finally, if $\mathrm{Ca}$ is dominant the mineral is calciosamarskite. Finally, the presence of iron $\left(\mathrm{Fe}^{2+}\right.$ or $\left.\mathrm{Fe}^{3+}\right)$ as a dominant $A$-site cation cannot be ignored. Even given a large potential for error, several samples are clearly enriched in these elements. Classification of these minerals based on $\mathrm{Fe}^{2+}$ and $\mathrm{Fe}^{3+}$ is fraught with problems as described above, thus it is impossible to determine if these minerals do occur in nature.

Ishikawaite and calciosamarskite are light rare-earth element (LREE) depleted and heavy rare-earth element (HREE) enriched with $\mathrm{Y}$ dominant. A chondrite-normalized plot (Fig. 3) shows that the enrichment of the HREE+Y relative to $L R E E$ is in excess of an order of magnitude. The Ishikawa sample exhibits a distinctive negative $\mathrm{Yb}$ anomaly. The reason for this is unknown.

\section{Conclusions}

Samarskite-group minerals are ordered $A^{3+} B^{5+} \mathrm{O}_{4}$ minerals and are a structural derivative of $\alpha-\mathrm{PbO}_{2}$ (Warner and Ewing, 1993). Samarskite-group minerals should include only those that have $\mathrm{Nb}$ $>\mathrm{Ta}$ and $\mathrm{Ti}$ in the $B$-site. Additionally, this group of minerals contains at least three species based on $A$-site chemistry. If $R E E+Y$ are dominant, the name samarskite- $(R E E+Y)$ should be used with the dominant of these cations as a suffix. If $U+T h$ are dominant, the mineral is properly named ishikawaite whereas if $\mathrm{Ca}$ is dominant, the mineral should be named calciosamarskite. Finally, iron is clearly dominant at the $A$-site in

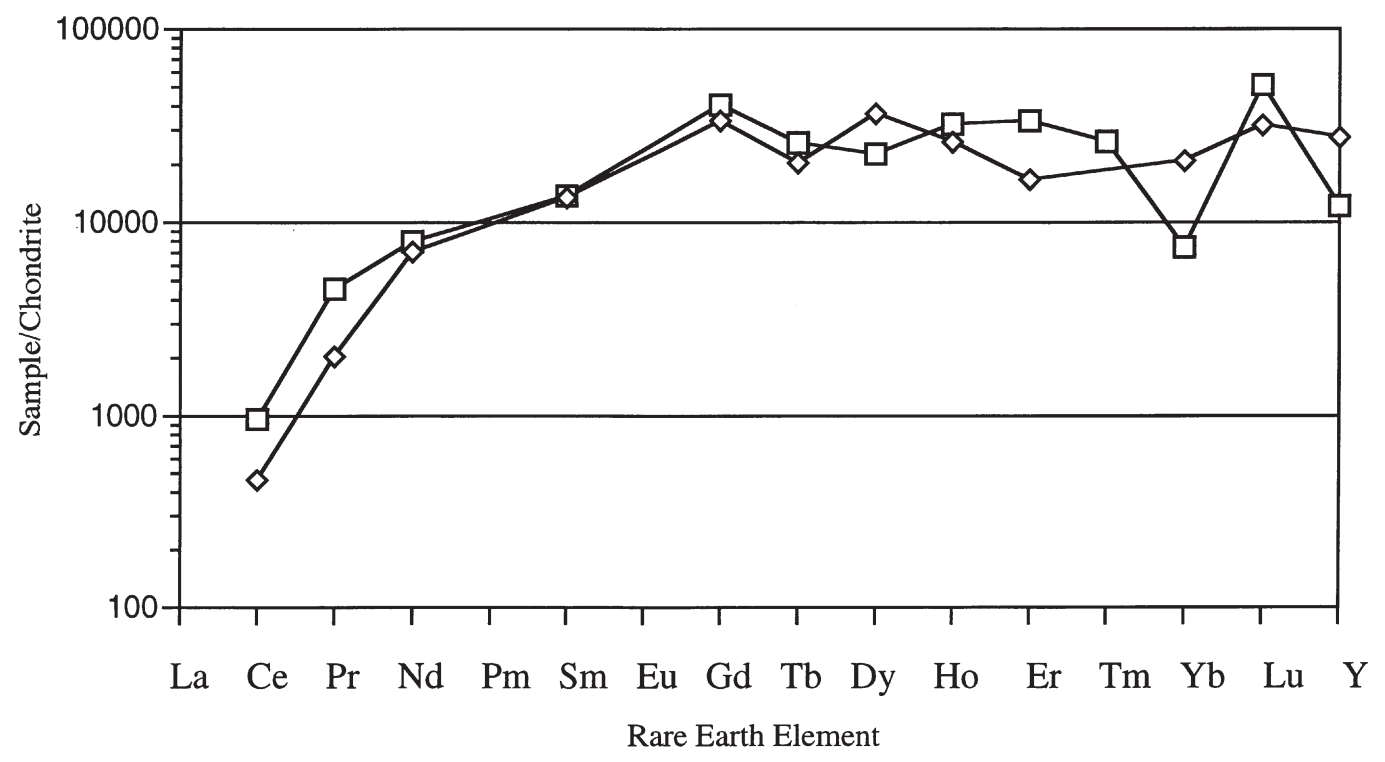

FIG. 3. Chondrite-normalized REE plot for all averaged ishikawaite and calciosamarskite analyses. Elements not shown as symbols are below the detection limit of the electron microprobe. Symbols are as in Fig. 1. 


\section{S. L. HANSON ETAL.}

some of these minerals. Because of the inability to quantify the valence state of iron in these minerals, the exact nature of these minerals cannot be determined

\section{Acknowledgements}

We wish to thank Michael Wise (U.S. National Museum) for providing us with the ishikawaite type specimen, R.H. Currier (Jewel Tunnel Imports) for the Kunar samarskite sample, Carl Francis (Peabody Museum of Archaeology and Ethnology, Harvard University) for the Mitchell Co. sample (Sample No. 97054) and W.P. Nash (Univ. of Utah) for time on the electron microprobe and help with the analyses. Water determinations were done by Larry L. Jackson (U.S. Geological Survey). We are also grateful to P.J. Modreski (U.S. Geological Survey) and R.C. Erd (U.S. Geological Survey) for helpful reviews which significantly improved this manuscript. We thank T. Scott Ercit for both reviewing this paper and sharing much unpublished information on samarskite-group minerals.

\section{References}

Appleman, D.E. and Evans, H.T. Jr. (1973) Job 9214 indexing and least squares refinement of powder diffraction data. U.S. Geological Survey, Comput. Contrib., 20 (NTIS Doc. PB2-16188).

Černý, P. and Ercit, T.S. (1989) Mineralogy of niobium and tantalum: crystal chemical relationships, paragenetic aspects and their economic implications. In Lanthanides, Tantalum, and Niobium (P. Moller, P. Cerný and F. Saupe, eds.). Springer Verlag, Berlin, 27-79.

Drake, M.J. and Weill, D.F. (1972) New rare earth element standards for electron microprobe analysis. Chem Geol., 10, 179-81.

Ellsworth H.V. (1928) A mineral related to samarskite from the Woodcox Mine, Hybla Ontario. Amer. Mineral., 13, 63-5.

Ewing, R.C. (1975) The crystal chemistry of complex niobium and tantalum oxides. IV. The metamict state: discussion. Amer. Mineral., 60, 179-81.

Fleischer, M. and Mandarino, J.A. (1995) Glossary of
Mineral Species 1995. The Mineralogical Record, Tucson, Arizona, 280 pp.

Hogarth, D.D. (1977) Classification and nomenclature of the pyrochlore group. Amer. Mineral., 62, 403-10.

Jackson, L.L. (1987) Major and minor elements requiring individual determinations, classical whole rock analyses, and rapid rock analyses. In U.S. Geological Survey Bulletin 1770 (P.A. Baedecker ed.). G1-G23.

Kimura, K. (1922) Ishikawaite; a new mineral from Ishikawa, Iwaki. J. Geol. Soc. Tokyo, 29, 316-20 (in Japanese).

Komkov, A.I. (1965) Crystal structure and chemical constitution of samarskite. Doklady Academii Nauk SSSR, Earth Science Section, 160, 127-9.

Nickel, E. H. (1992) Solid solutions in mineral nomenclature. Canad. Mineral., 30, 231-4.

Nickel, E.H. and Nichols, M.C. (1991) Mineral Reference Manual. Van Nordstrand Reinhold, New York, N.Y., 250 pp.

Nickel, E.H. and Mandarino, J.A. (1987) Procedures involving the IMA Commission on New Minerals and Mineral Names and guidlines on mineral nomenclature. Canad. Mineral., 25, 353-77.

Ohashi R. (1924) On Daiton sulfur, Arakawaite, and Ishikawaite. J. Geol. Soc. Tokyo, 31, 166-70 (in Japanese).

Palache, C., Berman, H. and Frondel, C. (1944) Dana's System of Mineralogy, Volume 1. Elements, Sulfides, Sulfosalts, Oxides, 7th ed. John Wiley and Sons, Inc. New York, 834 pp.

Pouchou, J.-L. and Pichoir, F. (1991) Quantitative analysis of homogenous or stratified microvolumes applying the model "PAP". In Electron Probe Quantification (K.F.J. Heinrich and D.E. Newbury, eds.). Plenum, New York, 31-75.

Sugitani, Y., Suzuki, Y. and Nagashima, K. (1984) Recovery of the original samarskite structure by heating in a reducing atmosphere. Amer. Mineral., 69, 377-9.

Sugitani, Y., Suzuki, Y. and Nagashima, K. (1985) Polymorphism of samarskite and its relationship to other structurally related $\mathrm{Nb}$-Ta oxides with the $\alpha$ $\mathrm{PbO}_{2}$ structure. Amer. Mineral., 70, 856-66.

Warner, J.K. and Ewing, R.K. (1993) Crystal chemistry of samarskite. Amer. Mineral., 78, 419-24.

[Manuscript received 6 February 1995:

revised 20 May 1998] 